\title{
PENINGKATAN HASIL BELAJAR MATEMATIKA SISWA DENGAN MEDIA KOMPUTER MODEL TUTORIAL INTERAKTIF PADA MATERI TRIGONOMETRI KELAS X-6
}

\author{
Hendra \\ SMAN 1 Bangkinang, Jl. Bendungan Uwai Bangkinang \\ Email: hendralazim@gmail.com
}

\begin{abstract}
The purpose of this study was to improved learning outcomes through the used of computer-based learning media interactive tutorial model on the subject of trigonometry students X-6 class SMA Negeri 1 Bangkinang academic year 2016/2017. Implementation of the learning processed in this study using two cycles consists of seven meetings with six lesson planed. During one cycle the observation of the implementation of the learning process and done reflection. The results of reflection are used as a reference to refine the action at the next meeting. Based on the analysis of the researcher and the discussion can be concluded that by applying computer-based learning media interactive tutorial model on trigonometric material can improve student's mathematics learning outcomes X-6 SMA Negeri 1 Bangkinang Bangkinang Sub-district, Kampar Semester Semester Even 2016/2017 learning year.
\end{abstract}

Keywords: Results of Mathematics Learning, Computer Media interactive tutorial model

\begin{abstract}
Abstrak
Tujuan penelitian ini adalah untuk meningkatkan hasil belajar melalui penggunaan media pembelajaran berbasis komputer model tutorial interaktif pada pokok bahasan trigonometri siswa kelas X-6 SMA Negeri 1 Bangkinang tahun pelajaran 2016/2017. Pelaksanaan proses pembelajaran pada penelitian ini menggunakan dua siklus terdiri dari tujuh kali pertemuan dengan enam rencana pembelajaran. Selama satu siklus dilakukan pengamatan terhadap pelaksanaan proses pembelajaran dan dilakukan refleksi. Hasil refleksi digunakan sebagai acuan untuk menyempurnakan tindakan pada pertemuan berikutnya. Berdasarkan analisis peneliti dan pembahasan dapat disimpulkan bahwa dengan menerapkan media pembelajaran berbasis komputer model tutorial interaktif pada materi trigonometri dapat meningkatkan hasil belajar matematika siswa kelas X-6 SMA Negeri 1 Bangkinang Kecamatan Bangkinang, Kabupaten Kampar Semester Genap tahun pembelajaran 2016 12017.
\end{abstract}

Kata kunci: Hasil Belajar Matematika, Media Komputer model tutorial interaktif

Hasil belajar matematika siswa masih rendah, aktifitas siswa juga masih rendah. Kenyataan ini tergambar pada hasil ulangan matematika dari 23 siswa kelas X-1 ternyata masih banyak siswa yang belum mencapai KKM yang ditetapkan sekolah yaitu 65. Hal ini terlihat pada Tabel-1 berikut.

Tabel 1.

Ketercapaian KKM Siswa Kelas XI IPA 1 SMA Negeri 1 Bangkinang Semester Genap Tahun Pelajaran 2015/2016

\begin{tabular}{|l|l|c|c|}
\hline No & \multicolumn{1}{|c|}{ Kompetensi Dasar } & $\begin{array}{c}\text { Jumlah siswa } \\
\text { mencapai KKM }\end{array}$ & $\begin{array}{c}\text { Persentase } \\
\text { Ketercapaian KKM }\end{array}$ \\
\hline 1 & $\begin{array}{l}\text { 5.1. Melakukan manipulasi aljabar } \\
\text { dalam perhitungan teknis yang } \\
\text { berkaitan dengan perbandingan, } \\
\text { fungsi, persamaan dan identitas } \\
\text { trigonometri }\end{array}$ & 6 & $26,08 \%$ \\
\hline
\end{tabular}




\begin{tabular}{|l|l|c|c|}
\hline 2 & 5.2. Merancang model matematika & & \\
& dari masalah yang berkaitan & 5 & $21,74 \%$ \\
dengan perbandingan, fungsi, & & \\
persamaan dan identitas & & \\
trigonometri & & \\
\hline
\end{tabular}

Berdasarkan Tabel 1 dapat dikatakan bahwa ketercapaian KKM siswa kelas X-1 SMA Negeri 1 Bangkinang masih rendah. Berdasarkan kenyataan tersebut, penulis mencoba mencari alternatif lain dalam proses pembelajaran matematika khususnya pokok bahasan trigonometri dengan memanfaatkan atau menggunakan media berbasis komputer model tutorial interaktif sehingga lebih merangsang siswa dalam melakukan aktivitas belajar dan dapat mengembangkan kemandirian siswa dan dapat membina tanggung jawab untuk dapat mencapai hasil belajar yang maksimal.

Penggunaan media akan dapat membangkitkan minat, motivasi dan juga dapat merangsang siswa untuk belajar. Sebagaimana yang diungkapkan oleh Hamalik (dalam Arsyad: 2006) bahwa pemakaian media pembelajaran dalam proses belajar mengajar dapat membangkitkan keinginan dan minat yang baru, membangkitkan motivasi dan rangsangan kegiatan belajar, dan bahkan membawa pengaruh-pengaruh psikologis terhadap siswa. Tujuan dalam penelitian ini adalah untuk meningkatkan hasil belajar melalui penggunaan media pembelajaran berbasis komputer model tutorial interaktif pada pokok bahasan trigonometri siswa kelas X-6 SMA Negeri 1 Bangkinang tahun pelajaran 2016/2017.

\section{METODE}

Penelitian ini merupakan Penelitian Tindakan Kelas (PTK). Penelitian dilaksanakan sebanyak dua siklus yaitu siklus I (pertama) dan siklus ke II (kedua). Setiap siklus terdiri dari perencanaan, tindakan, pengamatan, refleksi, kemudian dilakukan ulangan harian. Hasil pengamatan dan refleksi pada siklus I diadakan perbaikan/pemantapan pada proses pembelajaran pada siklus II. Sehingga tujuan untuk meningkatkan hasil belajar matematika siswa khususnya materi trigonometri menggunakan media komputer model tutorial interaktif dapat dicapai. Subjek dalam penelitian ini adalah siswa SMAN Bangkinang kelas X-6 tahun pelajaran 2016/2017 sebanyak 25 orang yang terdiri dari 7 orang laki-laki dan 17 orang perempuan.

\section{HASIL DAN PEMBAHASAN}

Pelaksanaan proses pembelajaran pada penelitian ini menggunakan dua siklus terdiri dari tujuh kali pertemuan dengan enam rencana pembelajaran. Selama satu siklus dilakukan pengamatan terhadap pelaksanaan proses pembelajaran dan dilakukan refleksi. Hasil refleksi digunakan sebagai acuan untuk menyempurnakan tindakan pada pertemuan berikutnya. 


\section{Siklus I}

Pertemuan pertama (rabu, 11 Januari 2017) materi yang dibahas yaitu menentukan perbandingan tronometri pada segitiga siku-siku, dengan beredoman pada RPP-I. Pada kegiatan awal guru mempersiapkan siswa untuk mempelajari cara penggunaan media pembelajaran berbasis komputer model tutorial interaktif. Pada kegiatan inti guru meminta masing-masing kelompok untuk mempelajari software media Pembelajaran berbasis komputer model tutorial tentang perbandingan trigonometri pada segitiga siku-siku. Setelah masing-masing kelompok mempelajari software media pembelajaran berbasis komputer model tutorial interaktif, masih banyak siswa yang belum mengerti cara menentukan nilai perbandingan trigonometri pada segitiga siku-siku. Kepada masing-masing kelompok, guru menjelaskan tahap demi tahap didalam menyelesaikan penentuan nilai perbandingan trigonometri pada segitiga siku-siku. Setelah siswa mengerti, kemudian guru membagikan lembar aktivitas siswa yang telah disiapkan.

Siswa secara berkelompok mengerjakan lembar aktivitas siswa dengan tujuan untuk mengetahui kemampuan siswa secara individu. Pada saat masing-masing kelompok siswa mengerjakan lembar aktivitas siswa masih ada siswa yang belum mengerti cara menentukan nilai perbandingan trigonometri yaitu mengalami kesulitan dalam menentukan sisi didepan, sisi pada dan sisi miring pada segitiga siku-siku. Kemudian guru kembali menjelaskan secara singkat bagaimana cara menentukan posisi sisi-sisi pada segitiga siku-siku.

Pada kegiatan akhir, guru bersama siswa merangkum materi pelajaran yang dipelajari, dan siswa menulisnya di dalam buku catatan masing-masing. Selanjutnya guru memberikan beberapa soal mengenai penentuan nilai perbandingan trigonometri pada segitiga siku-siku seperti pada RPP-I. Selanjutnya guru memberikan soal latihan untuk dikerjakan dirumah dan menginformasikan tentang materi pembelajaran pada pertemuan selanjutnya, yaitu menentukan nilai perbandingan trigonometri sudut istimewa/khusus. Berdasarkan hasil diskusi dengan pengamat diperoleh beberapa hal, Masih banyak siswa yang belum serius mempelajari materi yang ada pada software pembelajaran, dan Masih banyak siswa yang belum mengerti menggunakan media pembelajaran berbasis komputer model tutorial interaktif yang digunakan

Pertemuan kedua dilaksanakan pada senin, 16 Januari 2017. Pelaksanakaan pertemuan kedua sesuai dengan RPP-2 yang telah dibuat. Berdasarkan hasil diskusi dengan pengamat, proses pembelajaran belum sesuai dengan perencanaan. Dalam pelaksanaan belum sepenuhnya kegiatan dapat dilaksanakan oleh peneliti. Maka untuk mengatasi kelemahan ini maka peneliti akan memperbaiki pada pertemuan berikutnya.

Pertemuan ketiga dilaksanakan pada rabu, 18 Januari 2017. Pertemuan ketiga memabagas mengenai penentuan nilai perbandingan trigonometri untuk sudut di semua kuadran yang berpedoman pada RPP-3. Pertemuan keempat dilaksanakan pada hari senin, 23 Januari 2017. Pertemuan keempat 
membahas mengenai menggambar grafik fungsi trigonometri dengan berpedoman pada RPP-4. Pertemuan kelima dilaksanakan pada hari rabu, 25 Januari 2017. Pada pertemuan ini siswa mengerjakan ulangan harian I. Berdasarkan observasi yang dilaksanakan oleh pengamat selama tindakan untuk empat kali pertemuan, perencanaan yang tidak sesuai adalah:

1. Masih ada siswa yang belum diperhatikan secara seksama pada waktu mengerjakan soal-soal

2. Masih kurangnya komputer/laptop

3. Masih ada siswa yang belum fokus menyimak materi yang ada di media komputer

4. Rencana yang akan dilakukan guru untuk memperbaiki tindakan adalah:

5. Guru membimbing siswa satu persatu yang merasa segan untuk bertanya kepada guru.

6. Guru mengingatkan kembali materi yang telah dipelajari pada pertemuan sebelumnya yang berkaitan dengan materi yang sedang dipelajari, sehingga siswa termotivasi untuk belajar.

7. Guru menyuruh beberapa orang siswa untuk maju ke depan untuk mengerjakan soal yang telah diberikan.

8. Guru menganjurkan kepada semua siswa untuk mengulang kembali materi-materi yang belum dipahami dengan baik dengan cara memperhatikan kembali materi yang ada dalam media computer diluar jam tatap muka/ di rumah.

9. Setelah proses pembelajaran, guru dan siswa menyimpulkan materi yang telah dipelajari.

\section{Siklus II}

Siklus kedua dilakukan sebanyak lima kali pertemuan dengan satu kali adalah ulangan harian II. Pada siklus kedua guru membahas tentang aturan sinus, aturan kosinus, dan luas segitiga serta pemakaian perbandingan trigonometri dalam kehidupan sehari-hari. Pertemuan pertama pada siklus dua dilaksanakan pada rabu, 1 Februari 2017. Pertemuan ini membahas mengenai menentukan salah satu unsure segitiga jika diketahui tiga unsur (satu sudut dan sisi di depannya). Pertemuan kedua dilaksanakan pada tanggal 6 Februari 2017. Berdasarkan diskusi dengan pengamat, aktivitas guru sudah terlaksana dengan baik, sedangkan siswa masih ada yang mengalami kesulitan. Hal ini terjadi karena siswa belum paham menggunakan dalil Pythagoras serta masih ada siswa yang belum lancar perkalian.

Pertemuan kedelapan kegiatan pembelajaran membahas indikator menentukan luas segitiga dengan berpedoman pada RPP- 8. Berdasarkan diskusi dengan pengamat, pada pertemuan ini aktivitas guru dan siswa sudah berjalan dengan baik. Hal ini dikarenakan guru dan siswa sudah terbiasa dengan pembelajaran menggunakan media berbasis computer model tutorial interaktif. Pertemuan kesembilan dilaksanakan pada hari Senin 13 Februari 2017. Pertemuan kesepuluh dilaksanakan pada Rabu, 15 Februari 2017. Pada pertemuan ini, dilaksanakan ulangan harian II untuk mengetahui sejauh mana penguasaan siswa terhadap materi pelajaran yang telah dipelajari. Ulangan harian II dilaksanakan dalam waktu 2 x 45 menit dengan jumlah soal empat item. 
Berdasarkan observasi dan refleksi dari siklus kedua, diperoleh kesimpulan bahwa pembelajaran pada siklus kedua sudah lebih baik dari siklus pertama. Siswa sudah mengerti dan paham dengan tahaptahap pembelajaran yang dilaksanakan, sehingga tidak terlalu banyak siswa melakukan kesalahan dan siswa sudah mulai aktif dalam mengerjakan soal-soal. Hal ini tidak terlepas dari guru dalam membawakan materi pembelajaran dengan penerapan media pembelajaran computer model tutorial interaktif.

\section{Analisis Hasil}

\section{Aktivitas Guru dan Siswa}

Untuk mengetahui aktivitas guru dan siswa dalam proses pembelajaran dilakukan pengamatan terhadap aktivitas guru dan siswa selama proses pembelajaran. Data yang diperoleh melelui pengamatan dituliskan pada lembar pengamatan yang telah disediakan oleh peneliti untuk dianalisis. Pengamatan pertama aktivitas yang dilakukan guru masih banyak kelemahan-kelemahan dalam melaksanakan tahap-tahap pembelajaran, seperti memberikan motivasi kepada siswa, menjelaskan materi pelajaran. Sedangkan aktivitas siswa pada pertemuan pertama juga masih banyak kelemahankelemahan yang terjadi, seperti dalam mendengar motivasi yang diberikan oleh guru masih terdapat siswa yang kurang bersemangat mengikuti pelajaran yang akan dilaksanakan. Disamping itu masih banyak siswa yang belum dapat memahami sisi di depan sudut, sisi pada sudut, dan sisi miring pada segitiga siku-siku.

Pengamatan kedua, walaupun kelemahan-kelemahan yang terdapat pada pertemuan pertama sudah mulai diperbaiki, namun pada pertemuan kedua aktivitas guru masih saja terdapat kelemahankelemahan yang dilakukan dalam melaksanakan pembelajaran. Sedangkan aktivitas siswa, masih terdapat siswa yang kurang memperhatikan guru, saat guru menjelaskan materi pelajaran. Namun ada kemajuan, karena media pembelajaran berbasis komputer model tutorial interaktif dapat dipelajari secara mandiri oleh sebab itu siswa yang masih belum paham dapat mengulang materi tersebut diluar jam tatap muka.

Pengamatan ketiga, aktivitas guru sudah lebih baik, jika dibandingkan pada pertemuan sebelumnya. Sedangkan aktivitas siswa sudah menunjukkan banyak kemajuan dibandingkan dengan pertemuan pertama. Pengamatan keempat, aktivitas guru sudah sesuai rencana pelaksanaan pembelajaran, sedangkan aktivitas siswa pada pertemuan keempat masih ada beberapa orang yang masih diajarkan, namun aktivitas siswa lainnya sudah sesuai dengan perencanaan pembelajaraan.

Pengamatan kelima aktivitas guru sudah sesuai dengan rencana pelaksanaan. Sedangkan aktivitas siswa pada pertemuan kelima ini sudah sesuai dengan perencanaan pembelajaran. Pengamatan keenam, aktivitas guru sudah sesuai dengan perencanaan pembelajaran. Sedangkan aktivitas siswa sudah dapat dikatakan baik. Hal ini dapat dilihat bahwa siswa semakin bersemangat 
mengikuti keterangan guru, dan sebagian besar siswa sudah $\mathrm{n}$ guru, dan sebagian besar siswa sudah paham dan sudah mengerti tentang materi yang sudah pelajari.

\section{Analisis Ketercapaian Kriteria Ketuntasan Minimal KKM}

Untuk mengetahui skor hasil belajar trigonometri dan jumlah siswa yang nilainya mencapai KKM untuk setiap indicator pada ulangan harian I yang diperoleh siswa setelah melalui proses pembelajaran, dapat dilihat pada table-2 berikut.

Tabel 2.

Ketercapaian KKM untuk setiap indicator pada ulangan harian I.

\begin{tabular}{|c|l|c|c|}
\hline No & \multicolumn{1}{|c|}{ Indikator } & $\begin{array}{c}\text { Banyak siswa yang } \\
\text { mencapai KKM }\end{array}$ & $\begin{array}{c}\text { Persentase } \\
\text { Ketercapaian KKM }\end{array}$ \\
\hline 1 & $\begin{array}{l}\text { Menentukan nilai perbandingan } \\
\text { trigonometri pada segitiga siku- } \\
\text { siku }\end{array}$ & 13 & $52 \%$ \\
\hline 2 & $\begin{array}{l}\text { Menentukan nilai perbandingan } \\
\text { trigonometri dari sudut khusus }\end{array}$ & 21 & $84 \%$ \\
\hline 3 & $\begin{array}{l}\text { Menentukan nilai perbandingan } \\
\text { trigonometri dari sudut di semua } \\
\text { kuadran }\end{array}$ & 5 & $20 \%$ \\
\hline 4 & $\begin{array}{l}\text { Menggambar grafik fungsi } \\
\text { trigonometri sederhana }\end{array}$ & 1 & $4 \%$ \\
\hline
\end{tabular}

Berdasarkan Tabel 2. di atas dapat dilihat bahwa ulangan harian I sebagai cerminan siswa yang sudah memahami materi pelajaran yang disampaikan guru. Ada 12 orang yang belum mencapai KKM pada indikator pertama dikarenakan siswa tersebut tidak teliti dalam menyelesaikan soal yang diberikan oleh guru. Pada indikator kedua ada 4 siswa yang belum memahami materi pembelajaran, terutama dalam mengingat nilai perbandingan trigonometri sudut khusus/istimewa. Pada indikator ketiga ada 20 Siswa yang belum memahami materi pembelajaran terutama dalam perbandingan trigonometri sudut diberbagai kuadran menjadi perbandingan trigonometri sudut lancip. Pada indikator kempat ada 24 Siswa yang belum memahami materi pembelajaran terutama dalam menentukan letak titik koordinat di bidang kartesius. Menentukan nilai perbandingan trigonometri sudut diberbagai kuadran yang dapat diubah menjadi perbandingan trigonometri sudut lancip.Untuk mengetahui skor hasil belajar matematika dan jumlah siswa yang nilainya mencapai KKM untuk setiap indikator pada ulangan harian II yang diperoleh siswa setelah melalui proses pembelajaran dapat dilihat pada Tabel 3. sebagai berikut. 
Tabel 3.

Ketercapaian KKM untuk setiap indicator pada ulangan harian II.

\begin{tabular}{|c|l|c|c|}
\hline No & \multicolumn{1}{|c|}{ Indikator } & $\begin{array}{c}\text { Banyak siswa yang } \\
\text { mencapai KKM }\end{array}$ & $\begin{array}{c}\text { Persentase } \\
\text { Ketercapaian KKM }\end{array}$ \\
\hline 1 & $\begin{array}{l}\text { Menyelesaikan perhitungan soal } \\
\text { menggunakan aturan sinus }\end{array}$ & 13 & $52 \%$ \\
\hline 2 & $\begin{array}{l}\text { Menyelesaikan perhitungan soal } \\
\text { menggunakan aturan kosinus }\end{array}$ & 9 & $24 \%$ \\
\hline 3 & $\begin{array}{l}\text { Menghitung luas segitiga yang } \\
\text { komponennya diketahui }\end{array}$ & 6 & $20 \%$ \\
\hline 4 & $\begin{array}{l}\text { Menentukan penyelesaian dari } \\
\text { masalah yang berkaitan dengan } \\
\text { perbandingan, fungsi, } \\
\text { persamaan dan identitas } \\
\text { trigonometri }\end{array}$ & 5 & \\
\hline
\end{tabular}

Berdasarkan Tabel 3. dapat dilihat bahwa siswa sudah ada peningkatan yang mencapai ketuntasan pada setiap indikator. Pada indikator pertama ada 12 siswa yang belum mencapai KKM, dikarenakan masih banyak siswa yang belum mengerti cara menentukan invers sinus (anti sinus), padahal guru sudah maksimal dalam menjelaskan materi pembelajaran dan masih banyak siswa yang tidak mengulang mempelajari materi yang ada dalam software diluar jam tatap muka. Pada indikator kedua ada 16 siswa yang tidak tuntas, karena belum terlalu paham menggunakan aturan kosinus. Pada indikator ketiga ada 19 siswa yang tidak tuntas dikarenakan kurang mahir dalam mengubah rumus dan masih terkendala dalam olerasi aljabar. Sedangkan pada indikator keempat ada 20 siswa yang tidak tuntas disebabkan kurangnya pemahaman siswa dalam memahami soal cerita yang berhubungan dengan perbandingan, fungsi, persamaan, dan identitas trigonometri.

Peningkatan hasil belajar dari sebelum diberi tindakan ke setelah pemberian tindakan baik di siklus 1 maupun di siklus 2, belum begitu segnifikan hal ini disebabkan salah satu diantaranya adalah jumlah komputer/laptop yang digunakan belum begitu memadai (perbandingannya $1: 4$, satu komputer/laptop untuk 4 orang siswa, jadi setiap siswa tidak begitu leluasa dalam mempelajari materi yang ada dalam software media). Pembelajaran menunjukkan pada usaha siswa mempelajari bahan pelajaran sebagai akibat perlakuan guru, jadi proses pembelajaran yang dilakukan siswa tidak mungkin terjadi tanpa perlakuan guru (Sanjaya, 2010). Berarti jika guru melakukan perbaikan dalam pembelajaran dari siklus 1 ke siklus II akan mengindikasikan terjadinya perbaikan dari peserta didik dalam mempelajari bahan pelajaran sehingga akan terjadi peningkatan hasil belajar. Hal ini sejalan dengan hasil analisis terhadap hasil belajar matematika perserta didik yang mengalami peningkatan jumlah peserta didik yang mecapai KKM dari skor dasar ke uangan harian I dan ulangan harian II.

Berdasarkan data ketercapaian KKM peserta didik kelas X6 SMAN 1 Bangkinang tahun pelajaran 2016/2017 yang disajikan pada tabel 4 . 
Tabel 4.

Ketercapaian KKM Peserta Didik Kelas X6 SMAN 1 Bangkinang

\begin{tabular}{|c|c|c|}
\hline \multirow{2}{*}{ Nilai } & \multicolumn{2}{|c|}{ Yang Mencapai KKM } \\
\hline & Banyak Peserta Didik & Persentase \\
\hline Skor Dasar & & \\
\hline Ulangan Harian I & 11 & $44 \%$ \\
\hline Ulangan Harian II & 11 & $44 \%$ \\
\hline
\end{tabular}

Berdasarkan Tabel 4. terlihat bahwa terjadi peningkatan jumlah peserta didik yang mencapai KKM dari skor dasar ke ulangan harian I dan ulangan harian II. Disebabkan hasil belajar siswa setelah tindakan lebih baik dari hasil sebelum tindakan, maka dapat dikatakan tindakan sudah berhasil. Jika keberhasilan tindakan pada siklus I dibandingkan dengan hipotesis tindakan yang pertama maka dapat disimpulkan bahwa hasil penelitian ini mendukung hipotesis tindakan yang pertama. Sehingga hipotesis tindakan yang pertama, yaitu "hasil belajar metematika dapat meningkat melalui penerapan media pembelajaran berbasis komputer model tutorial interaktif di kelas X6 SMA Negeri 1 Bangkinang tahun pelajaran 2016/2017 pada kompetensi dasar Melakukan manipulasi aljabar dalam perhitungan teknis yang berkaitan dengan perbandingan, fungsi, persamaan dan identitas trigonometri" dapat diterima kebenarannya. Berdasarkan hasil analisis keberhasilan tindakan juga diketahui pada siklus II dikatakan berhasil. Jika keberhasilan tindakan pada siklus II dibandingkan dengan hipotesis tindakan yang kedua maka dapat disimpulkan bahwa hasil penelitian ini mendukung hipotesis tindakan kedua. Sehingga hipotesis tindakan yang kedua, yaitu "hasil belajar mtematika dapat meningkat melalui penerapan Media Pembelajaran Berbasis Komputer Model Tutorial Interaktif di kelas X6 SMA Negeri 1 Bangkinang pada kompetensi dasar Merancang model matematika dari masalah yang berkaitan dengan perbandingan, fungsi, persamaan dan identitas trigonometri" juga dapat diterima kebenarannya.

\section{KESIMPULAN}

Berdasarkan analisis peneliti dan pembahasan dapat disimpulkan bahwa dengan menerapkan media pembelajaran berbasis komputer model tutorial interaktif pada materi trigonometri kelas X-1 SMA Negeri 1 Bangkinang Kecamatan Bangkinang Kabupaten Kampar Semester Genap tahun pembelajaran 2016 / 2017. Berdasarkan pembahasan hasil tindakan, maka yang akan menjadi saran pada penelitian ini adalah sebagai berikut: 
1. Pembelajaran dengan menggunakan media pembelajaran berbasis komputer model tutorial interaktif dapat dijadikan sebagai salah satu alternative media pembelajaran yang dapat diterapkan oleh guru dalam melaksanakan proses pembelajaran di sekolah.

2. Kepada peneliti yang berminat menindaklanjuti penelitian ini diharapkan lebih memperhatikan waktu, karena pembelajaran menggunakan media komputer dapat membuat siswa lalai dalam mempelajari materi yang ada dalam software.

3. Sebelum pelaksanaan tindakan peneliti perlu memberikan sosialisasi kepada peserta didik bagaimana menggunakan/cara-cara menggunakan media berbasis komputer model tutorial interaktif agar jalannya pembelajaran dapat berjalan seperti yang diharapkan.

4. Kepada peneliti agar memperhatikan jumlah komputer yang digunakan, sebaiknya satu siswa satu komputer supaya masing-masing siswa lebih leluasa mempelajari materi yang ada dalam software medianya.

\section{DAFTAR PUSTAKA}

Amin Senin. (1992). Sumbangan Islam dalam bidang matematika. Kuala Lumpur : Datuk Keramat. Anas Sudijono. (2005). Pengantar Statistik Pendidikan. Jakarta: Raja Grafindo Persada.

Arends, Richard I. (2008). Learning to Teach Belajar untuk Mengajar buku satu edisi ketujuh. Yogyakarta : Pustaka Pelajar

Arif Ismail, Mohd. Ph.D. dkk. (2009). Integrasi Teknologi Mobile dalam Pembelajaran, Pekanbaru: Cendikia Insani.

Arief S. Sadiman. (2008). Media Pendidikan Pengertian, Pengembangan, dan Pemanfaatanya. Jakarta: PT. Raja Grafindo Persada.

Asep Jihad. (2008). Pengembangan Kurikulum Matematika Tinjauan Teoritis dan Historis. Yogyakarta: Multi Pressindo.

Asri Budiningsih. (2005). Belajar dan Pembelajaran. Jakarta: PT. Rineka Cipta.

Azhar Arsyad. (2006). Media Pembelajaran. Jakarta: PT. Raja Grafindo Persada.

Dhani Yudhiantoro. (2006). Membuat animasi WEB dengan macromedia flash profesional 8. Yogyakarta : Andi Offset.

Depdiknas. (2003). Media Pembelajaran. Jakarta : Depdiknas.

Depdiknas. (2009). Materi Diklat/Bimtek KTSP SMA, Jakarta : Depdiknas.

Dimyati dan Mudjiono. (2006). Belajar dan Pembelajaran. Jakarta: Rineka Cipta.

Herman Hudoyo. (1979). Pengembangan kurikulum Matematika dan pelaksanaannya di depan kelas. Surabaya : Usaha Nasional.

Mahmud Khalifah. (2009). Menjadi Guru yang dirindu. Surakarta: Ziyad Visi Media.

Nana Sudjana. (2009). Penilaian Hasil Proses Belajar Mengajar. Bandung: PT. Remaja Rosdakarya. 
Oemar Hamalik. (2006). Proses Belajar Mengajar, Jakarta: Bumi Aksara

Sartono Wirodikromo. (2006). Matematika SMA, Jakarta : Erlangga.

Suharsimi Arikunto. (1999). Dasar-dasar Evaluasi Pendidikan. Jakarta: Bumi Aksara.

Wina Sanjaya. (2008). Perencanaan dan sistem pembelajaran, Jakarta: Kencana Prenada media group. 